\title{
New developments in the pathology of malignant lymphoma: a review of the literature published from January to August 2009
}

\author{
J. Han van Krieken
}

Published online: 26 September 2009

(C) Springer-Verlag 2009

\section{Introduction}

The previous issue of the Journal of Hematopathology lacked a review of the literature because there were five commentaries on the 2008 classification by members of the editorial team [1-5] and the first regular review on literature for bone marrow pathology by Jon VanderWalt [6]. Therefore, this issue contains a quite long review of the literature covering the first half of 2009, a longer period compared to the previous three reviews [7-9] and the selection was therefore, more strict.

The wealth of information that is coming available is more and more difficult to grasp, and reviews like this can only lift a tip of the veil. Huang et al. [10] have developed an intelligent database that enables to integrate many data that are available on lymphoma patients. Since the majority of patients are not the average patient, this type of approach may be helpful to reach a level of knowledge that will enable real personalized medicine, by comparing many data of an individual patients to those present in the database. In principle, the opposite approach to collecting large amounts of data and comparing that to individual patients is to try to unravel the pathogenesis of lymphomas by experimental work. Also in the last months, exiting new data have become available which will eventually lead to more biological approaches in the treatment of lymphoma patients.

Blocking the effect of gene activation by mRNA interference is a promising approach for various tumor

\section{J. H. van Krieken $(\bowtie)$}

Department of Pathology,

Radboud University Nijmegen Medical Centre, P.O. Box 9101, 6500 HB Nijmegen, The Netherlands

e-mail: j.vankrieken@pathol.umcn.nl types. It is therefore quite helpful that Anastasov et al. [11] were able to develop an efficient lentiviral vector-based system to study gene knockdown in lymphoid cell lines. The work will form the foundation of a series of studies on the effect of knocking out specific proteins in cell cultures.

\section{Biology of lymphoma}

Hodgkin lymphoma

Now that a large amount of biological features of Hodgkin lymphoma (HL) tumor cells has become available, amongst others, by studying cell lines, several new drugs are being tested preclinically. Hartlapp et al. [12] show that targeting multiple signaling pathways by inhibition of histone deacetylase using depsipeptide results in apoptosis induction and cell cycle inhibition. Especially the inhibition of apoptsis had been difficult to achieve so far, and thus, this might be a promising new treatment for HL patients.

It is now well-known that HL represents a B cell neoplasia with an aberrant B cell differentiation program. Jones et al. [13] pursue an already old observation that in the culture of HL cell lines small populations of phenotypic normal B cells occur that express immunoglobulin. They were able to demonstrate that this small population is the precursor and generator of the HL cells, and also that such cell can be found in the blood of HL patients, regardless of stage.

B cell lymphomas

As referred to in the previous review [9], the tumor microenvironment was the main topic at the European Association of Heamatopathology symposium in Bordeaux 
in 2008. It became very clear that this is an important topic, but that our understanding is far from complete. Maby-El Haijami et al. [14] show that resting human mesenchymal stem cells (MSC) sustain activated normal B cell proliferation and survival, whereas IFN-gamma-conditioned MSCs mediate B cell growth arrest and apoptosis. IFN-gamma, TNF, and lymphotoxin-alphalbeta2 (LT) are significantly overexpressed by the microenvironment of follicular lymphoma (FL), but their relative expression patterns are highly heterogeneous between samples. In vitro, IFNgamma abrogates the B cell supportive phenotype induced by TNF and LT on MSCs. Moreover, IFN-gamma overrules the growth promoting effect of MSCs on primary purified FL B cells. Altogether, these results underline the crucial role of the cytokine context in the local crosstalk between malignant cells and their microenvironment and provide new insights into our knowledge of the FL cell niche that emerges as a new promising target for innovative therapeutic strategies. But cytokines have not only an effect on MSCs. Especially in FL it is well-known that T cells are an important component of the microenvironment. Yang et al. [15] show that in B cell lymphoma samples the amount TH17 cells is decreased and by using cell cultures they showed that this is due to IL-2 production by malignant $\mathrm{B}$ cells, that activates regulatory $\mathrm{T}$ cells, which in turn downregulates the number of TH17 cells. In mantle cell lymphoma (MCL), Kurtova et al. [16] found high levels of CXCR4, CXCR5, and VLA-4. Since these chemokine receptors and adhesion molecule enable cell motility and migration, this finding may explain the often early high stage of disease patients present with.

The relation between $\mathrm{B}$ and $\mathrm{T}$ cells was even more intimate in observations by Krejsgaard et al. [17]. It was already known that B-lymphoid kinase (Blk), normally expressed in $B$ cells and thymocytes only, transferred into mature $T$ cells results in T cell lymphomas. They observed that Blk can be found in cutaneous $T$ cell lymphomas, but not in benign $T$ cell infiltrates, a finding when confirmed is quite relevant.

Anti CD20 antibodies are now a cornerstone in the therapy of B cell lymphomas. Rossi et al. [18] developed bispecific antibodies, anti CD20/CD22, and showed that in vitro these lead to apoptosis of $\mathrm{B}$ cells, and more efficiently in B cell lymphoma cells.

The relation between specific infections and extranodal marginal zone lymphomas (MZL) is well-known, with $\mathrm{H}$. Pylori (HP) activating specific anti-HP T cells driving the lymphoma cells as prime example. The mechanism may be different in ocular marginal zone lymphomas since Bahler et al. [19] show that these lymphomas use specific immunoglobulin VH gene segments. Furthermore, the mutation spectrum suggests antigen-driven selection, and thus a potential antigen may have a more direct effect on the tumor cells in these cases.
Novak et al. [20] were able to demonstrate another common feature in MZL of various sites. Homozygous deletions of the chromosomal band 6q23, involving the tumor necrosis factor alpha-induced protein 3 (TNFAIP3, A20) gene, a negative regulator of NF-kappa B, had already been described in ocular adnexal MZL. Inactivating mutations encoding truncated A20 proteins were present in six $(19 \%)$ of 32 MZLs, including two $(18 \%)$ of 11 extranodal MZLs, three (33\%) of nine nodal MZLs, and one $(8 \%)$ of 12 Splenic MZLs. Two additional unmutated nonsplenic MZLs also showed monoallelic or biallelic A20 deletions by fluorescent in situ hybridization (FISH) and/or SNP-arrays. Thus, A20 inactivation by either somatic mutation and/or deletion represents a common genetic aberration across all MZL subtypes. These findings are to be taken with care, since many other features clearly distinguish SMZL from the other two types.

Mantle cell lymphoma is a very widely studied tumor type, and may have a highly complex karyotype next to the characteristic $\mathrm{t}(11 ; 14)$. Wang et al. [21] show that MCL have high levels of Jun kinases (JNK) mitogen-activated protein kinase, and that this is needed for cell proliferation and maintaining diploidy. In a subset of MCL's, loss of JNK results in a hyperdiploid state.

Now that technology to study genome-wide methylation has become available, it is no surprise that also lymphomas are studied using this powerful method. Bennett et al. [22] analyzed FL and compared the results to benign lymph follicles. The results indicate that extensive hypermethylation in promoters of polycomb target genes is a characteristic of FL, and that loss of expression of certain SUZ12 target genes could be functionally relevant for lymphomagenesis. Using a more traditional approach, Kondo et al. [23] found that gastric lymphomas, both MZL and diffuse large B cell lymphomas (DLBL), have many hypermethylated CGP islands, and that in gastric specimens without lymphoma, only hypermethylation was seen in case of HP infection. This suggests that hypermethylation may be an early event in EMZL lymphomas under the influence of HP infection.

Interleukin (IL)-21 has been recently shown to modulate the growth of specific types of B cell neoplasm, and MCL expresses the IL21 receptor. Gelebart et al. [24] show that IL-21 can effectively induce apoptosis in MCL via a STAT1-dependent pathway, which may be useful in designing novel therapeutic approaches.

Although the frequent occurrence of bcl- 6 abberations in DLBL is well-known, the functional consequences were enigmatic. In a series of elegant experiments, Saito et al. [25] show a link between bcl-6 and bcl-2 in DLBL explaining the mutual exclusive gene alteration of bcl-2 and bcl-6. In normal germinal center B cells, BCL6 binds to the BCL2 promoter region by interacting with the transcriptional activator Miz1 and suppresses Miz1-induced 
activation of BCL2 expression. BCL6-mediated suppression of BCL2 is lost in FL and DLBCL, where the two proteins are pathologically coexpressed, because of BCL2 chromosomal translocations and other mechanisms, including Miz1 deregulation and somatic mutations in the BCL2 promoter region. These results identify an important function for BCL6 in facilitating apoptosis of germinal centre (GC) B cells via suppression of BCL2, and suggest that blocking this pathway is critical for lymphomagenesis.

Although the association between Burkitt lymphoma (BL) and Epstein-Barr virus (EBV) infection is wellknown, the exact mechanism by with the virus results in lymphoma development is not clear: in BL-cells, EBV is not always present. It has been suggested that EBV-positive and EBV-negative BL have different cells of origin. In particular, according to immunoglobulin gene mutation analysis, EBV-negative BLs may originate from early centroblasts, whereas EBV-positive BLs appears to arise from postgerminal center B cells or memory B cells. Leucci et al. [26] found that hsa-miR-127 is differentially expressed between EBV-positive and EBV-negative BLs. In particular, it was strongly upregulated only in EBV-positive BL samples, whereas EBV-negative cases showed levels of expression similar to normal controls, including microdissected GC cells. In addition, they found evidence that hsa-miR-127 is involved in B cell differentiation process through post transcriptional regulation of BLIMP1 and XBP1. The overexpression of this mRNA may thus represent a key event in the lymphomagenesis of EBV positive BL, by blocking the B cell differentiation process.

The Janus kinase 2 (JAK2)-signal transducers and activators of transcription pathway plays an important role in hematological malignancies. Mutations and translocations of the JAK2 gene, mapped at 9p24, lead to constitutive activation of JAK2 and its downstream targets. The presence of JAK2 mutations in lymphomas has been addressed in larger cohorts, but there are little systemic data on numerical and structural JAK2 aberrations in lymphoid neoplasms. Using TMAs and FISH with split signal JAK 2 probes, Meier et al. [27] show that 9p24 gains were present in six of $17(35 \%)$ primary mediastinal B cell lymphomas, 25 of 77 (33\%) Hodgkin's lymphomas, three of $16(19 \%)$ angioimmunoblastic $\mathrm{T}$ cell lymphomas, and one of five ALK1 (+) anaplastic large cell lymphomas; breaks were observed only in three cases. They stress that despite the rarity of activating JAK2 mutations in lymphomas, JAK2 is recurrently targeted by numerical, and rarely by structural, genetic aberrations in distinct lymphoma subtypes.

$\mathrm{T}$ cell lymphoma

The mechanism causing chromosomal translocations involving antigen receptors are quite well understood, but much more limited ideas exist on other translocations. Mathas et al. [28] investigated anaplastic large cell lymphoma (ALCL) cases with and without a $t(2 ; 5)$ translocation and found that that several genes near both breakpoints are dysregulated regardless of whether the translocation is present. The authors speculate that the activity of these genes may be related to the occurrence of the translocation itself, thereby assuming the both types of ALCL represent the same entity.

Also, Lim et al. [29] show that many more genes than those involved in the translocation are aberrantly expressed in ALCL. Using mass spectrometry, they identified protein expression signatures related to, amongst others, cell survival and angiogenesis. They also found that a subset of proteins distinguished ALK-positive from ALK-negative cases.

Singh et al. [30] focused on the sonic hedgehog signaling ( $\mathrm{SHH})$ pathway, and demonstrate that this pathway is activated in ALK-positive ALCL due to SHH gene amplification and is further mediated by NPM-ALK through activation of PI3K/AKT and stabilization of GLI1 protein. Dien Bard et al. [31] look into the JAK3/STA3 activation which is known to be present in ALK-positive ALCL using cell lines and tumor samples, and shows that next to other factors, IL-21 contributes to that activation. Finally, although overexpressed at the RNA level, Bobos et al. [32] could not detect overexpression of cyclinD1 at the protein level in ALCL. All this work indicates the complexity of tumorigenesis in lymphomas, even in a type that has such a characteristic translocation as Alk-positive ALCL.

\section{Epidemiology of lymphoma}

Etiological studies into lymphomas are difficult, due to the rarity of the different types of lymphoma. The role of the Epstein-Barr virus is well-established, especially in individuals with a reduced $\mathrm{T}$ cell function. The polyomavirus SV40 has been detected with various incidences and its role is not so clear. Toracchio et al. [33] investigated lymphoma tissue for the presence of these two viruses. They show that in Houston, there exist a difference in frequency of the polyomavirus and EBV, with $23 \%$ and $39 \%$ in one hospital and $3 \%$ and $18 \%$ in another, whereas the lymphoma type distribution was similar. The polyomavirus occurred more often in younger patients and in T cell lymphomas. These results show that marked differences in involvement of viruses occur even in areas from the same city. Another virus that is involved in the pathogenesis of some lymphomas is the Human herpesvirus 8 (HHV8), especially in patients with HIV. According to a study by Chen et al., [34] on 52 posttransplant lymphoproliferative disorders, HHV8 does not play a role in this entity. 
Given the fact the lymphomas arise in immune compromised patients and that germline polymorphisms are wellknown for solid cancers, it does not come as a surprise that such polymorphisms are relevant in lymphoma development too. Morton et al. [35] studied almost 2000 patients and controls for the presence of single nucleotide polymorphisms (SNP's) in 203 genes and found significant differences between patients with specific lymphoma types and controls. They indicate that the results support the role of genetic variation in cell cycle, apoptosis, and lymphocyte development regulatory genes in lymphomagenesis, and suggest that effects may vary by nonhodgkin lymphoma (NHL) subtype.

Geographical variation in incidence of lymphoma types is well-known. In most cases, the cause of this variation is not clear. An important point to understand this variation lies in case definition and molecular findings. A Chinese series of chronic lymphocytic leukemia (CLL) was molecularly characterized revealing some remarkable differences. In China, CLL is rare and the most frequent cytogenic findings were the occurrence of $14 q$ breaks in $24 \%$ of the cases (Irons et al. [36]). The mutation status was prognostically significant, like in Western series, but in contrast, trisomy 12 was not.

\section{Defining entities}

\section{Hodgkin lymphoma}

The diagnosis of lymphocyte rich classical HL (cHL) can be difficult. Nam-Cha et al. [37] compared this type of HL with the other types of cHL and with nodular lymphocyte predominant (NLP)-HL. Lymphocyte-rich cHL displayed features intermediate between those of cHL and NLP-HL. The expression of B cell transcription factors such as Oct.1, Oct.2, Bob.1, and BCL6 was more frequent in lymphocyterich $\mathrm{cHL}$ than in $\mathrm{cHL}$. A follicular T cell microenvironment was also identified in $50 \%$ of lymphocyte-rich classical Hodgkin's lymphoma cases. NF-kB markers were expressed at frequencies comparable with those observed in cHL. Lymphocyte-rich cHL was characterized by a stronger expression of the $\mathrm{B}$ cell transcription program by the neoplastic cells and by a follicular T cell background, occupying an intermediate position between cHL and NLP-HL. According to a study of Bharqava et al. [38] on 35 archival cases of NLP-HL $(n=24)$ and LRcHL $(n=11)$ from adults and children, fascin and junB expressions can be used as markers to separate these subtypes: Whereas, occasional $\mathrm{L}$ and $\mathrm{H}$ cells were weakly positive for fascin in three out of $24(12.5 \%)$ cases of NLP-HL, RS cells in LRCHL were positive for fascin in 11 out of $11(100 \%)$ cases with a strong cytoplasmic staining pattern. JunB was positive in ten out of $24(41.7 \%)$ of NLP-HL cases, and 11 out of $11(100 \%)$ of LRCHL cases, showing a stippled and/or diffuse nuclear staining pattern. The $\mathrm{L}$ and $\mathrm{H}$ cells of NLP-HL cases were negative for concomitant staining in 24 out of $24(100 \%)$ cases. Concomitant positive staining of classic RS cells for fascin and JunB was found in 11 out of $11(100 \%)$ of LRCHL cases.

Lymphocyte depleted (LD) HL had been a bit neglected the last years, but regained interest lately (see previous review; 9). Slack et al. [39] studied eight cases that fulfilled diagnostic criteria of LDHL according to the 2008 World Health Organization classification. The cases involved lymph nodes (seven cases) and pleura (one case) from four males and four females (age 30-71 years; median 62 years). All tumors contained numerous Hodgkin-Reed Sternberg (HRS) cells, fibroblasts and histiocytes, and scattered lymphocytes. In three cases, the tumors had a more diffuse fibrotic appearance, while in five cases they appeared reticular and anaplastic. Neoplastic cells in all cases expressed CD30, CD15, fascin, weak PAX5, and MUM-1 and lacked CD45, Alk-1, EMA, CD3, CD68, Mart-1, and cytokeratin. Oct.2 and/or Bob-1 were expressed in all cases. Two cases variably expressed CD20 but were CD79a negative. Four cases were positive for EBV. All the four cases with adequate DNA had clonally rearranged IGH genes. The combined morphologic, immunophenotypic and molecular genetics features of this group of cases distinguish LDHL from other disease entities, including gray-zone lymphomas.

\section{B cell lymphomas}

Precursor B-lymphoblastic leukemia/lymphoma is according to the WHO-classification one entity, although the clinical presentation of the lymphoma cases differs markedly from the leukemic ones. Schaders et al. [40] used genomic profiling and found that there are subtle but significant differences between the two types of presentation, whereas that was not the case for T-lymphoblastic lymphoma/leukemia. Whether or not this indicates that this points to a different pathogenesis remains unclear.

After it became clear in the late eighties of the previous century, mainly through work of Peter Isaacson, that nodal and extranodal lymphomas are different, many studies into lymphomas of specific sites have been published. Schniederjan et al. [41] describe 40 lymphomas from the urinary tract and genital organs (but not testis and ovary). This study confirms the predominance of diffuse large B cell lymphoma in extranodal sites, the findings also highlight the variety of lymphomas that may occur in the genitourinary tract; only four cases of marginal zone lymphoma were seen, all in the kidney, none in the bladder. This diversity of subtypes affirms the importance of fully 
characterizing lymphomas by immunohistochemistry and other modalities. Validire et al. [42] describe 45 lymphomas with breast incolvement, 38 of which were DLBL. Most cases had lymph node involvement and thus were not primary breast lymphomas. The survival data confirm that nodal lymphomas that present with extranodal involvement have a poorer outcome. Mozos et al. [43] describe a series of ten cases of the rare primary adrenal lymphoma. Histologically, eight cases were DLBL, all of which carried a nongerminal center B cell phenotype. Fluorescence in situ hybridization revealed BCL6 gene rearrangement in five $(83 \%)$ of six DLBL investigated. The prognosis of these patients was poor as compared with those with nodal DLBL. The remaining cases were one case each of plasmablastic lymphoma and extranodal NK/T cell lymphoma, nasal type, the first and third case of primary adrenal lymphoma of these particular lymphoma subtypes in the English literature, respectively.

Yin et al. [44] describe six new cases of CLL with $\mathrm{t}(2 ; 14)$, involving the Bcl11A gene. This series differs from other cases of CLL since they have irregular nuclei and plasmacytoid differentiation and all were unmutated.

CD103 is a good marker for hairy cell leukemia (HCL), but other lymphoproliferations with CD103 expression exist. Dong et al. [45] describe 215(!) CD103-positive lymphoproliferations. Almost 80\% coexpressed CD25 indicative of HCL, all of which were annexin-A1 positive. All cases negative for annexin-A1 lacked CD25 also. The remaining $20 \%$ of cases had a variable morphology and phenotype representing HCL variant, splenic marginal zone lymphoma, prolymphocytic leukemia, and DLBL and did not respond to stand HCL therapy. It is actually curious that such treatment had been given to those patients.

Ongoing studies of the Kluin-group in Groningen into testicular and central nervous lymphomas (so called immune-privileged sites) have shown several specific features of this group of DLBL. In a study on the expression of 15 microRNAs (miRNAs) of 50 DLBL (19 localized nodal, 11 testicular, nine CNS, and 11 other extranodal ones) they show that MiR-17-5p has higher expression level in the CNS cases compared to testicular and nodal DLBL. MiR-127 levels were higher in testicular than in central nervous system and in nodal DLBL. They conclude that the site of presentation of DLBL is an important factor in determining the differential expression of miRNAs (Robertus et al. [46]).

For CLL, the mutation status of the immunoglobulin gene is an important prognostic factor, but for MCL this is not so clear. Schraders et al. [47] show, using many clinical and pathological features, including $\mathrm{CGH}$ and expression array, that mutation status in this disease does not indicate a clinical and biological subentity.
Translocation $\mathrm{t}(11 ; 18 ; \mathrm{q} 21 ; \mathrm{q} 21)$ is the most frequent chromosomal aberration reported in gastric mucosaassociated lymphoid tissue lymphomas. Intriguingly, this translocation has been reported only rarely in diffuse large $\mathrm{B}$ cell lymphomas; it has been proposed that $\mathrm{t}(11 ; 18)$ positive tumors rarely progress to diffuse large B cell lymphomas. Torrachio et al. [48] investigated the occurrence of this translocation in primary gastric lymphomas, both MZL and DLBL. Remarkably, the frequency was similar in both groups, about $20-25 \%$. It is an intriguing question whether this might also indicate response to HP eradication in the BLBL cases.

Nodal marginal zone lymphoma (NMZL) is difficult to diagnose, since there is not a specific phenotype. Especially the differentiation from FL is sometimes difficult. Kanellis et al. [49] selected from expression array data myeloid cell nuclear differentiation antigen (MNDA), a nuclear protein expressed by myeloid cells and a subset of $B$ cells. MNDA was expressed in subgroups of CLL, MCL, and DLBL, but MNDA was especially expressed by lymphomas derived from the marginal zone, such as mucosa-associated lymphoid-tissue lymphoma, splenic MZL, and NMZL. MNDA expression was rarely observed in FL, a characteristic that is of potential value in distinguishing NMZL from FL.

The $\mathrm{t}(14 ; 18)$ is the hallmark of $\mathrm{FL}$, but various frequencies of negative cases are described, depending on the technique used to detect the translocation. A series of 17 $t(14 ; 18)$ negative FL was studied by Leich et al. [50], and they found that in contrast to positive cases, no numerical aberrations in the bcl 2 region and in addition a different gene expression profile. Remarkably, the cases were weak or negative for $\mathrm{CD} 10$, which opens the question whether cases might represent nodal marginal zone lymphomas with completely colonized germinal centers. A remarkably large series of $t(14 ; 18)$ negative FL ( 63 out of 142 cases of FL) was investigated by Gu et al. [51] using FISH and show that there is a similar frequency of bcl6 breaks compared to $\mathrm{t}(14 ; 18)$ positive cases, but that the breakpoint differs.

Two studies on FL of the spleen were done. Howard et al. [52] describe 16 cases, all with bcl2 or bcl6 breaks, positive for bcl2 and CD10, but often pure intrafollicular growth, which makes the differential diagnosis with reactive lesions difficult. Spleen weight remains an important issue! A series of 32 cases by Mollejo et al. [53] had different results: 20 had weak or absent bcl 2 staining and many of these were CD10 negative and lacked a break in bcl2. This latter group had a higher proliferation rate and was more often restricted to the spleen. It is likely that such cases have been given another diagnosis, i.e., marginal zone lymphoma, by Howard et al. [52]

Chromosomal breaks in the MYC gene are characteristic for Burkitt lymphoma but occur also in progressed 
lymphomas and DLBL. Such cases have an aggressive clinical course and it is debated whether morphological features point towards cases with potential MYC break. Obermann et al. [54] studied 333 DLBL with FISH for MYC, and had a reliable result in 220 of these. Only nine (4\%) had a MYC break but these could not be predicted using conventional methods, including proliferative index. The authors suggest that routine screening of DLBL for MYC break is needed, but with such a low percentage, a cost-effectiveness study is called for. In BL, MYC breaks are not the only genomic change and Molina-Privado et al. [55] provided evidence based on studies in cell lines and tumor samples that E2F1 is also overexpressed in almost all sporadic BL.

Korac et al. [56] investigated the expression of FoxP1 in multiple myeloma and monoclonal gammopathy of undetermined significance and show that there is expression in contrast to normal plasma cells, and also that there is an increased gene copy number.

\section{$\mathrm{T}$ cell lymphomas}

In celiac disease patients, abnormal T-lymphocytes may occur intraepithelial in the small bowel. Using flow cytometry Verbeek et al. [57] analyzed the T-lymphocytes in celiac disease patients with aberrant $\mathrm{T}$ cells in the lamina propria and in skin lesions, and found that also in these compartments, aberrant cells can be found.

Cho et al. [58] reiterate the difficulties that may occur in evaluating staging bone marrow biopsies from patients with angioimmunoblastic $\mathrm{T}$ cell lymphoma (AILDT). In a series of 33 patients, about $70 \%$ had a positive marrow, but about one-third had been missed initially. Especially when clinical data are lacking cases with a mixed infiltrate were not recognized.

Rarely, $\mathrm{T}$ cell lymphomas have a follicular growth pattern, and such cases are suggested to be associated with t $(5 ; 9)$. Huang et al. [59] studies 30 such cases and that these are often CD4, CD10, Bc16, PD-1, CXCL13, and ICOS positive, a pattern that is similar to that of follicular helper T cells; four of 22 had the translocation. Three patients had in-follow biopsies AILDT.

Falchook et al. [60] describe their experience with 15 patients who had gamma-delta $\mathrm{T}$ cell lymphoma and confirmed the poor outlook in this disease: Median overall survival was 11 months (range 2 to $36+$ months)

Most cases of $\mathrm{T}$ cell large granular lymphocytosis carry the alpha beta $\mathrm{T}$ cell receptor, but occasional cases have gamma delta receptors. Shaw et al. [61] describe two such cases which appeared in most clinical and pathological features very similar to the common type.

Although it is well known that CD99 is not specific for a certain disease, it is remarkable that 103 out of 160 ALCL stain for this antibody. In contrast to the suggestion of Buxton et al. [62], this antibody was not initially described as a marker for Ewings sarcoma, but for precursor T cells. The tumor cells in ALCL are, however, mature T cells.

A very large series of 136 cases of primary CD4 positive cutaneous $\mathrm{T}$ cell lymphoma was described by Beltraminelli et al. [63]. Patients with skin nodules characterized by the infiltrate of pleomorphic small/medium $\mathrm{T}$ lymphocytes are currently classified as "primary cutaneous CD4+ small-/ medium-sized pleomorphic T cell lymphoma" or as T cell pseudolymphoma. The distinction is often arbitrary, and patients with similar clinicopathologic features have been included in both groups. All but three patients presented with solitary nodules located mostly on the head and neck area $(75 \%)$. Histopathologic features were characterized by nonepidermotropic, nodular, or diffuse infiltrates of smallto medium-sized pleomorphic T lymphocytes. A monoclonal rearrangement of the $\mathrm{T}$ cell receptor-gamma gene was found in $60 \%$ of tested cases. Follow-up data available for 45 patients revealed that 41 of them were alive without lymphoma after a median time of 63 months (range: 1-357 months), whereas, four were alive with cutaneous disease (range: 2-16 months). The incongruity between the indolent clinical course and the worrying histopathologic and molecular features poses difficulties in classifying these cases unambiguously as benign or malignant, and it may be better to refer to them with a descriptive term such as "cutaneous nodular proliferation of pleomorphic $\mathrm{T}$ lymphocytes of undetermined significance," rather than forcing them into one or the other category.

\section{New entities/subtypes}

The data on IgG4 disease are accumulating fast. Sato et al. [64] compare IgG4-related lymphadenopathy (nine cases) with multicentric Castleman's disease. Histologically, systemic IgG4-related lymphadenopathy was classified into two types by the infiltration pattern of IgG4-positive cells: interfollicular plasmacytosis type and intragerminal center plasmacytosis type. The interfollicular plasmacytosis type showed either Castleman's disease-like features or atypical lymphoplasmacytic and immunoblastic proliferation-like features. By contrast, the intragerminal center plasmacytosis type showed marked follicular hyperplasia, and infiltration of IgG4-positive cells mainly into the germinal centers, and some cases exhibited features of progressively transformed germinal centers. Since eight of the nine cases had eosinophil infiltration in the affected tissue and elevation of serum IgE, the authors suggest an allergic mechanism in the pathogenesis of systemic IgG4-related lymphadenopathy.

Chen et al. [65] describe five B cell neoplasias with CDK6 translocation. Common clinical characteristics 
included marked neoplastic lymphocytosis, systemic lymphadenopathy, splenomegaly, and bone marrow involvement. Three patients were diagnosed with lowgrade B cell lymphoma and had an indolent clinical course, and two patients (one who transformed to large B cell lymphoma, and the other who was initially diagnosed with a high-grade B cell lymphoma) had an aggressive clinical course. Immunophenotypically, the neoplastic B cells expressed CD5, CDK6, and cytoplasmic retinoblastoma 1 protein in all cases, expressed phospho-RB, p27kip1, and cyclin D2 in most cases, and uniformly lacked expression of all other cyclins. In four cases, the CDK6 translocation partner was kappa immunoglobulin light-chain gene; and in the fifth case, the CDK6 translocation partner was unknown. These distinct clinicopathologic and cytogenetic features distinguish the CDK6 translocation-associated BLPDs from other mature B cell lymphomas.

EBV-positive lymphomas of the elderly have received quite some attention recently. Gibson et al. [66] collected six such cases in the US, where this disease seems rare. They also screened 60 cases of DLBL, in which no case was EBER positive. The six cases were similar as described by the Japanese, and also as posttransplant cases.

Maeshima et al. [67] screened 529 cases of DLBL and found 38 (7.2\%) cases positive for CD5. Five cases gained CD5 expression during the clinical course of DLBCL. Three cases showed transformation from CD5- low-grade B cell lymphoma to CD5+ DLBCL. The remaining case showed coexistence of CD5+ DLBCL and CD5+ follicular lymphoma. The clonal relationships of CD5- and CD5+ tumors were confirmed in all four available cases. These results indicate that cases in the east differ from those in the west, since no MCL were in this group, and CD5 is seldom seen in Western cases.

Although methotrexate-associated lymphoproliferations receive less attention in the last WHO classification, it remains an important topic. Such cases need withdrawal of the drug rather than chemotherapy, but can only be recognized when the information on the fact that the patient uses methotrexate is available to the pathologist. Cases look very much like regular DLBL or HL or AILT according Hatanaka et al. [68], based on three cases.

\section{Prognostic factors in lymphoma}

Again, the largest number of articles referred this time deal with prognostic factors. As I discussed in the previous review [9], the issue now is to have predictive factors. In this period, an important paper was published that comes up with a predictive factor. It is widely accepted that at least two groups of DLBL exists, the activated and germinal centre type, and that these are prognostically different.
Dunleavy et al. [69] show that bortezomib enhances the effect of chemotherapy in patients with activated B cell like DLBL and not in the germinal center type. This makes the subclassification, for which still no reliable immunohistochemical approach exists, quite relevant. A next step will be a clinical trial that takes this information into account. Another study that preludes on a predictive approach investigates the expression of CD52 in T cell lymphomas, since ant-CD52 antibodies become available. Jiang et al. [70] determined by flow cytometry in $78 \mathrm{~T}$ cell neoplasias the level of CD52 expression. All AITL, hepatosplenicTCL and T-PLL cases were CD52-positive but CD52 expression was low in ALCL (50\%) and ENT/NKCL $(25 \%)$. Although the authors suggest that this finding may be important for treatment selection, clinical data are needed to determine the minimum level of expression that warrants treatment with the anti CD52 antibody.

Troncone et al. [71] had shown that high UbcH10 expression indicates aggressive behavior in solid tumors and now studied this enzyme in lymphomas, both on cell lines and tissue samples of a variety of types. They show that UbcH10 expression is related to proliferation and that high expression is found in aggressive lymphomas, the highest in BL.

Marquard et al. [72] studied the expression levels of a series of proteins of histone deacetylase system, which is targeted by several new drugs. The shows that HDAC1, HDAC2, HDAC6, and acetylated $\mathrm{H} 4$ are overexpressed in DLBCL and PTCL relative to normal lymphoid tissue. Furthermore, HDAC6 indicated favorable outcome in DLBCL and a more aggressive course in PTCL.

Diepstra et al. [73] studied a large series of 412 patients with classical HL for the clinical relevance of EBV-infection. About one-third was positive and these had a better 5 years survival, but only in the age group from 50-74 years. In this age, group EBV negative cases had a 5 years survival of only $60 \%$ versus $85 \%$.

Retuximab is now a cornerstone in the treatment of B cell lymphomas. Johnson et al. [74] show that mutation in this gene are rare and not prognostically relevant in B cell lymphomas at diagnosis and relapse, so mutation analysis of the CD20 gene has no role in routine practice.

It is quite clear that the future of array studies leis in the use of formalin-fixed and paraffin-embedded tissues. Sanchez-Espiridion et al. [75] studied such tissues from 52 cases of HL with a low-density array and were able to successfully use more than $80 \%$ of the samples and develop a predictor for relapse free survival. A more standard approach was taken by Canioni et al. [76] who studied 59 cases with immunohistochemistry: expression of bcl2 and CD20 in Hodgkin and Reed Sternberg cells, and expression of TiA1 in microenvironmental lymphocytes, and c-kit positive mast cells in microenvironment, were independent prognostic markers. 
Bhagavathi et al. [77] used an even more classical approach in FL where they analyzed the growth pattern in 457 patients in relation to survival. Since they found no independent value of this factor, reporting the amount of follicular growth is not necessary. In contrast, according Carreras et al. [78] the amount of PD-1 positive T cells is; a high content is in a multivariate analysis does predict a favorable outcome. It is a pity that in this series now known prognostic factors like intrafollicular growth fraction and vessel density (Koster et al. [79, 80], 2x) were not taken along.

FoxP1 expression was studied in gastric extranodal MZL by Han et al. [81]. About half the cases had nuclear expression, which was correlated with shorter survival. It is remarkable that in these patients surgery was often the primary treatment, and the $\mathrm{t}(11 ; 18)$ status and HP eradication data were not given. Sumida et al. [82] looked into that specifically by analyzing HP-eradication success in $t(11 ; 18)$ positive cases; as expected, none of these responded, nor did any $f$ the HP negative cases. In HP-positive, $t(11 ; 18)$ positive responders' serum titers of antibodies against HP and the CagA protein were higher than in nonresponders.

Several studies reported on prognostic factors in DLBL, most of them took the activated-B and germinal center type into account, although most study use the poor correlating immunohistochemical profile for that. The 92 patients of Ilic et al. [83] with immunohistochemically determined GCB-type DLBCL did not have an improved prognosis, irrespective of whether they had received rituximab or not. According to Morito et al. [84], low serum soluble interleukin-2 receptor levels and germinal center B celllike cases in 80 patients treated with rituximab were predicting favorable outcome, but the results correlate strongly with the IPI. Although these two markers may substitute the IPI according to the authors, it seems to me that the IPI is so well-established and easy to use, that this will not happen.

Johnson et al. [85] report on 54 lymphomas with bcl2 and MYC translocations. These cases were classified as B cell lymphoma unclassifiable with features intermediate between Burkitt lymphoma and diffuse large B cell lymphoma (DLBCL) [36], DLBCL [17] or follicular lymphoma [1]. Non-immunoglobulin gene/MYC (non-IG/MYC) translocations occurred in 24 of 54(44\%) and were highly associated with DLBCL morphology $(p<0.0001)$. A non-IG/MYC translocation partner, absent BCL2 protein expression and treatment with rituximabbased chemotherapy were associated with a more favorable outcome but a low IPI score and DLBCL morphology were independent predictors of OS.

An interesting study was reported by Balague et al. [86], who analyzed the expression of activated $\mathrm{X}$ box-binding protein 1 (Xbp-1) in reactive lymphoid tissues, 411 lymphomas and plasma-cell neoplasms, and $24 \mathrm{~B}$ cell lines. $\mathrm{Xbp}-1$ is a transcription factor that is required for the terminal differentiation of B lymphocytes into plasma cells. The Xbp-1 gene is activated in response to endoplasmic reticulum stress signals, which generate a $50-\mathrm{kDa}$ nuclear protein that acts as a potent transactivator and regulates the expression of genes related to the unfolded protein response. Activated Xbp-1 is essential for cell survival in plasma-cell tumors. None of the low-grade lymphomas showed evidence of Xbp-1 activation; however, Xbp-1 activation was found in $28 \%$ of diffuse large B cell lymphomas, independent of germinal or postgerminal center phenotype, as well as in $48 \%$ of plasmablastic lymphomas and $69 \%$ of plasma-cell neoplasms. Diffuse large B cell lymphomas with nuclear Xbp-1 expression had a significantly worse response to therapy and shorter overall survival compared with negative tumors.

In 20 primary cutaneous follicle center cell lymphomas, Soltani-Arabshahi et al. [87] found that high RNA expression levels of bcl-xL were related to low numbers of apoptotic cells and indicated poor survival, whereas bcl-2 levels were not.

In 44 patients with nodal DLBL, Lee at al describe that out of a series of eight genes studies, MGMT and p57 methylation correlated with better prognosis, dependent on risk status. According to Curry et al. [88], based on 68 cases, c-Rel expression (65\%) indicates better survival, but only in the germinal center B subgroup. Kim et al. [89] found the sonic hedgehog signaling proteins are more prevalent in DLBL and patients with high expression of ABCG2 have short survival (67 cases).

In a series of 30 PTCL, Briones et al. [90] investigated the role of bcl10 and show that Bcl-10 is expressed in twothirds of the PTCLs, correlates with the expression of upstream proteins PKC theta and Pp65(Ser536) and is associated with better survival.

The amount of information on regulatory $\mathrm{T}$ cells (Treg) is increasing fast, even though debate on their precise phenotype in humans is ongoing. Using only FOXP3 as marker for these cells, Kim et al. [91] show that in 64 cases of extranodal NK/TCL high numbers of Treg are associated with better survival, and that this is an independent prognostic marker.

A few studies deal with prognostic markers for cutaneous TCL. In the erythrodermic group (124 cases, Vidulich et al. [92]), serum LDH and age were the strongest predictive factors for overall survival. ALCL (48 cases; Woo et al. [93]) run an aggressive course in patients presenting with extensive limb disease. In MF (70 cases; Chandra et al. [94]), clusterin expression was in about half of the patients, and especially in those with many large atypical cells and high stage. 


\section{Staging}

Although it is well-known that bone marrow involvement is rare in cutaneous lymphomas, and according to the WHO classification in fact excludes the diagnosis of primary cB-NHL, it is not clear whether all patients with cB-NHL need to undergo a bone marrow biopsy. Based on a series of 57 patients, with only three positive marrows, Quereux et al. [95] conclude that this investigation is not indispensible.

Most pathologists now perform routine immunohistochemistry to detect limited involvement of the bone marrow in staging biopsies. According to Baiyee et al. [96]., based on 113 cases of DLBL, CD20 staining does not enhance sensitivity, even not in histologically discordant cases, which were about $40 \%$ of their $10 \%$ positive cases.

Ilgenfritz et al. [97] investigated the value of molecular analysis for staging of the bone marrow in comparison with routine methods. They conclude on data from 60 patients that IGH PCR alone is not good enough for bone marrow assessment, especially in FL. On the other hand, the PCR study for BCL2 is more sensitive than morphology, without any false negative results in this series, suggesting that BCL2-MBR PCR can be used as an alternative and more sensitive examination for disease evaluation, providing that there is careful analysis of data, adequate knowledge of PCR pitfalls and absence of other hematological disorders. These latter remarks are quite important and preclude the use in routine practice.

\section{Ancillary techniques}

Detection of leptomeningeal disease may influence treatment of patients with aggressive B-NHL. Quijano et al. [98] used advanced flow cytometrical (FCM) approaches and found that $27(22 \%)$ of 123 patients showed infiltration by FCM, while conventional cytology (CC) was positive in only seven patients $(6 \%)$, with three other cases being suspicious $(2 \%)$. $\mathrm{CC}+/ \mathrm{FCM}+$ samples typically had more than $20 \%$ neoplastic B cells and/or $>$ or $=$ one neoplastic B cell/microL, while FCM+/CC- samples showed lower levels of infiltration. Interestingly, in Burkitt lymphoma, presence of CNS disease by FCM could be predicted with a high specificity when increased serum beta2-microglobulin and neurological symptoms coexisted, while peripheral blood involvement was the only independent parameter associated with CNS disease in diffuse large B cell lymphoma, with low predictive value. A similar study, but on a variety of lymphoma types and in only 32 cases by $\mathrm{Wu}$ et al. [99] came to the same conclusion.

Fine needle aspirations are more and more done, also to diagnose and classify lymphomas. Although HL is regarded as a disease that can be reliably diagnosed on cytological specimens, Das et al. [100] show that in about $25 \%$ of HL diagnosis on cytology, the histological diagnosis was different. When flow cytometry is added (252 cases of NHL, Demurtas et al. [101]) diagnostic sensitivity and specificity of the combination cytomorphology/FC were $97 \%$ and $94 \%$, respectively. This therefore, might reduce the number of invasive lymph node resections, especially from difficult to reach sites.

Fromm et al. [102] looked into the reliability of flow cytometry for the diagnosis of HL in lymph nodes. Of the 53 morphologically defined CHL cases identified, the FC assay diagnostic sensitivity and specificity were $88.7 \%$ and $100 \%$, respectively. With the current availability of eight (or more) color clinical flow cytometers, this assay can now be applied to routinely immunophenotype and confirm a diagnosis of CHL or as an adjunct to immunohistochemical analysis. However, this study does also show that there is no added value above standard practice.

Intraocular lymphoma is very difficult to diagnose due to the limited amount of cells that can be obtained. Sugita et al. [103] show that using clonality testing and cytokine profiling (IL6 and IL10) is very usefull to come to a reliable diagnosis (22 patients). A completely different and new approach was taken by Pantanelli et al. [104], who used autofluorescence of cells in preclinical models and were able to separate B- from T cells. Since the main differential diagnosis from a B cell lymphoma in the uvea is uveitis, and thus a $\mathrm{T}$ cell infiltrate, this approach is promising.

Clonality testing has become routine practice in most laboratories for hematopathology. There are several wellknown pitfalls. Fan et al. [105] studied liver biopsies from 40 hepatitis $\mathrm{C}$ virus infected patients and 800 controls. In the hepatitis group, light chain restriction was present in four $(10 \%)$ and three $(0.4 \%)$ in the controls. In five of these seven, a clonal IgH rearrangement was found, and two of these five patients proved to have a B cell lymphoma. So clonality does not always indicate malignancy and light chain restriction not always clonality. It is well-known that HL is a B cell lymphoma, and with the new Biomed approach for clonality testing, that includes detection of incomplete rearrangements, it could be expected that HL samples will give clonal results. Hebeda et al. [106] show that out of $24 \mathrm{cHL}$ samples, 19 (79\%) proved to be clonal using standard clonality testing with the Biomed primers, i.e., without enrichment by dissection of the tumor cells.

Several proteomic approaches are being tried for classification of lymphomas, as discussed in an earlier review. Now, Miquet et al. [107] did a mass spectrometry of plasma membrane microparticles on 158 patients with chronic B cell proliferation and 30 controls. This resulted in the confirmation of CD 148 as a good marker for MCL, specificity of $91 \%$, but sensitivity of $78 \%$. 
Romesser et al. [108] build further on their gene expression array work in a mouse model, where they were able to translate the results in protein patterns and conclude that results support the central hypothesis that clusters of proteins of known function represent a panel of expression markers uniquely associated with malignancy and not normal proliferation. A fact that conclusion was already supported by the work of Jansen et al. [109], although their approach made identification of individual proteins not possible.

\section{References}

1. Lim MS, de Leval L, Quintanilla-Martinez L (2009) Commentary on the 2008 WHO classification of mature T- and NK-cell neoplasms. J Hematop 2:65-73

2. Lim MS (2009) Commentary on the WHO 2008 classification of neoplasms arising from histiocytic and other accessory cells. J Hematop 2:75-76

3. Ott G, Balague-Ponz O, de Leval L, de Jong D, asserjian RP, Elenitoba-Johnson KS (2009) Commentary on the WHO classification of tumors of lymphoid tissues (2008): indolent B cell lymphomas. J Hematop 2:77-81

4. Balague Ponz O, Ott G, Hasserjian RP, Elenitoba-Johnson KS, de Leval L, de Jong D (2009) Commentary on the WHO classification of tumors of lymphoid tissues (2008): aggressive B cell lymphomas. J Hematop 2:83-87

5. Hasserjian RP, Ott G, Elenitoba-Johnson KS, Balague-Ponz O, de Jong D, de Leval L (2009) Commentary on the WHO classification of tumors of lymphoid tissues (2008): "gray zone" lymphomas overlapping with Burkitt lymphoma or classical Hodgkin lymphoma. J Hematop 2:89-95

6. van der Walt J (2009) Recent advances in bone marrow biopsy pathology. J Hematop 2:97-102

7. van Krieken JH (2008) New developments in the pathology of malignant lymphoma: a review of the literature published from January to April 2008. J Hematop 1:37-45

8. van Krieken JH (2008) New developments in the pathology of malignant lymphoma: a review of the literature published from May to July 2008. J Hematop 1:145-160

9. van Krieken JH (2009) New developments in the pathology of malignant lymphoma: a review of the literature published from August to December 2008. J Hematop 2:50-61

10. Huang T, Shenoy PJ, Sinha R, Graiser M, Bumpers KW, Flowers CR (2009) Development of the lymphoma enterprise architecture database: a caBIG(tm) silver levelcompliant system. Cancer Inform 8:45-64

11. Anastasov N, Klier M, Koch I, Angermeier D, Höfler H, Fend F, Quintanilla-Martinez L (2009) Efficient shRNA delivery into B and $\mathrm{T}$ lymphoma cells using lentiviral vector-mediated transfer. $\mathrm{J}$ Hematop 1:9-19

12. Hartlapp I, Pallasch C, Weibert G, Kemkers A, Hummel M, Re D (2009) Depsipeptide induces cell death in Hodgkin lymphoma-derived cell lines. Leuk Res 33:929-936

13. Jones RJ, Gocke CD, Kasamon YL, Miller CB, Perkins B, Barber JP, Vala MS, Gerber JM, Gellert LL, Siedner M, Lemas MV, Brennan S, Ambinder RF, Matsui W (2009) Circulating clonotypic B cells in classic Hodgkin lymphoma. Blood 113:5920-5926

14. Maby-El Hajjami H, Amé-Thomas P, Pangault C, Tribut O, DeVos J, Jean R, Bescher N, Monvoisin C, Dulong J, Lamy T,
Fest T, Tarte K (2009) Functional alteration of the lymphoma stromal cell niche by the cytokine context: role of indoleamine-2, 3 dioxygenase. Cancer Res 69:3228-3237

15. Yang ZZ, Novak AJ, Ziesmer SC, Witzig TE, Ansell SM (2009) Malignant $\mathrm{B}$ cells skew the balance of regulatory $\mathrm{T}$ cells and TH17 cells in B-cell non-Hodgkin's lymphoma. Cancer Res 69:5522-5523

16. Kurtova AV, Tamayo AT, Ford RJ, Burger JA (2009) Mantle cell lymphoma cells express high levels of CXCR4, CXCR5, and VLA-4 (CD49d): importance for interactions with the stromal microenvironment and specific targeting. Blood 113:4604-4613

17. Krejsgaard T, Vetter-Kauczok CS, Woetmann A, Kneitz H, Eriksen KW, Lovato P, Zhang Q, Wasik MA, Geisler C, Ralfkiaer E, Becker JC, Ødum N (2009) Ectopic expression of B-lymphoid kinase in cutaneous T-cell lymphoma. Blood 113:5896-5904

18. Rossi EA, Goldenberg DM, Cardillo TM, Stein R, Chang CH (2009) Hexavalent bispecific antibodies represent a new class of anticancer therapeutics: 1. Properties of anti-CD20/CD22 antibodies in lymphoma. Blood 113:6161-6171

19. Bahler DW, Szankasi P, Kulkarni S, Tubbs RR, Cook JR, Swerdlow SH (2009) Use of similar immunoglobulin VH gene segments by MALT lymphomas of the ocular adnexa. Mod Pathol 22:833-838

20. Novak U, Rinaldi A, Kwee I, Nandula SV, Rancoita PM, Compagno M, Cerri M, Rossi D, Murty VV, Zucca E, Gaidano G, Dalla-Favera R, Pasqualucci L, Bhagat G, Bertoni F (2009) The NF-\{kappa\}B negative regulator TNFAIP3 (A20) is inactivated by somatic mutations and genomic deletions in marginal zone lymphomas. Blood 113:4918-4921

21. Wang M, Atayar C, Rosati S, Bosga-Bouwer A, Kluin P, Visser L (2009) JNK is constitutively active in mantle cell lymphoma: cell cycle deregulation and polyploidy by JNK inhibitor SP600125. J Pathol 218:95-103

22. Bennett LB, Schnabel JL, Kelchen JM, Taylor KH, Guo J, Arthur GL, Papageorgio CN, Shi H, Caldwell CW (2009) DNA hypermethylation accompanied by transcriptional repression in follicular lymphoma. Genes Chromosomes Cancer 48:828-841

23. Kondo T, Oka T, Sato H, Shinnou Y, Washio K, Takano M, Morito T, Takata K, Ohara N, Ouchida M, Shimizu K, Yoshino T (2009) Accumulation of aberrant $\mathrm{CpG}$ hypermethylation by Helicobacter pylori infection promotes development and progression of gastric MALT lymphoma. Int J Oncol 35:547-557

24. Gelebart P, Zak Z, Anand M, Dien-Bard J, Amin HM, Lai R. Interleukin-21 effectively induces apoptosis in mantle cell lymphoma through a STAT1-dependent mechanism. Leukemia (2009). doi:10.1038/leu.2009.100

25. Saito M, Novak U, Piovan E, Basso K, Sumazin P, Schneider C, Crespo M, Shen Q, Bhagat G, Califano A, Chadburn A, Pasqualucci L, Dalla-Favera R (2009) BCL6 suppression of BCL2 via Miz1 and its disruption in diffuse large B cell lymphoma. Proc Natl Acad Sci USA 106:11294-11299

26. Leucci E, Onnis A, Cocco M, De Falco G, Imperatore F, Antonicelli G, Costanzo, Cerino G, Mannucci S, Cantisani R, Nyagol J, Mwanda W, Iriso R, Owang M, Schurfeld K, Bellan C, Lazzi S, Leoncini L (2009) B cell differentiation in EBV-positive Burkitt Lymphoma is impaired at post-transcriptional level by miRNA altered expression. Int J Cancer. Jun 15 (in press)

27. Meier C, Hoeller S, Bourgau C, Hirschmann P, Schwaller J, Went P, Pileri SA, Reiter A, Dirnhofer S, Tzankov A (2009) Recurrent numerical aberrations of JAK2 and deregulation of the JAK2-STAT cascade in lymphomas. Mod Pathol 22:476-487

28. Mathas S, Kreher S, Meaburn KJ, Jöhrens K, Lamprecht B, Assaf C, Sterry W, Kadin ME, Daibata M, Joos S, Hummel M, Stein H, Janz M, Anagnostopoulos I, Schrock E, Misteli T, 
Dörken B (2009) Gene deregulation and spatial genome reorganization near breakpoints prior to formation of translocations in anaplastic large cell lymphoma. Proc Natl Acad Sci USA 106:5831-5836

29 Lim MS, Carlson ML, Crockett DK, Fillmore GC, Abbott DR, Elenitoba-Johnson OF, Tripp SR, Rassidakis GZ, Medeiros LJ, Szankasi P, Elenitoba-Johnson KS (2009) The proteomic signature of NPM/ALK reveals deregulation of multiple cellular pathways. Blood 114(8):1,585-1595

30. Singh RR, Cho-Vega JH, Davuluri Y, Ma S, Kasbidi F, Milito C, Lennon PA, Drakos E, Medeiros LJ, Luthra R, Vega F (2009) Sonic hedgehog signaling pathway is activated in ALK-positive anaplastic large cell lymphoma. Cancer Res 69:2550-2558

31. Dien Bard J, Gelebart P, Anand M, Zak Z, Hegazy SA, Amin HM, Lai R (2009) IL-21 contributes to JAK3/STAT3 activation and promotes cell growth in ALK-positive anaplastic large cell lymphoma. Am J Pathol 175:825-834

32. Bobos M, Kotoula V, Kaloutsi V, Karayannopoulou G, Papadimitriou CS, Kostopoulos I (2009) Aberrant CCND1 copies and cyclin D1 mRNA expression do not result in the production of functional cyclin D1 protein in anaplastic large cell lymphoma. Histol Histopathol 24:1035-1048

33. Toracchio S, Kozinetz CA, Killen DE, Sheehan AM, Banez EI, Ittmann MM, Sroller V, Butel JS (2009) Variable frequency of polyomavirus SV40 and herpesvirus EBV in lymphomas from two different urban population groups in Houston, TX. J Clin Virol. 46(2):154-160

34. Chen W, Huang Q, Zuppan CW, Rowsell EH, Cao JD, Weiss LM, Wang J (2009) Complete absence of KSHV/HHV-8 in posttransplant lymphoproliferative disorders: an immunohistochemical and molecular study of 52 cases. Am J Clin Pathol 131:632-639

35. Morton LM, Purdue MP, Zheng T, Wang SS, Armstrong B, Zhang Y, Menashe I, Chatterjee N, Davis S, Lan Q, Vajdic CM, Severson RK, Holford TR, Kricker A, Cerhan JR, Leaderer B, Grulich A, Yeager M, Cozen W, Hoar Zahm S, Chanock SJ, Rothman N, Hartge P (2009) Risk of non-Hodgkin lymphoma associated with germline variation in genes that regulate the cell cycle, apoptosis, and lymphocyte development. Cancer Epidemiol Biomarkers Prev 18:1259-1270

36. Irons RD, Le A, Bao L, Zhu X, Ryder J, Wang XQ, Ji M, Chen Y, Wu X, Lin G (2009) Characterization of chronic lymphocytic leukemia/small lymphocytic lymphoma (CLL/ SLL) in Changhai, China: Molecular and cytogenetic characteristics, $\operatorname{IgV}$ gene restriction and hypermutation patterns. Leuk Res (in press)

37. Nam-Cha SH, Montes-Moreno S, Salcedo MT, Sanjuan J, Garcia JF, Piris MA (2009) Lymphocyte-rich classical Hodgkin's lymphoma: distinctive tumor and microenvironment markers. Mod Pathol 22:1006-1015

38. Bhargava P, Pantanowitz L, Pinkus GS, Pinkus JL, Paessler ME, Roullet M, Gautam S, Bagg A, Kadin ME (2009) Utility of Fascin and JunB in Distinguishing Nodular Lymphocyte Predominant From Classical Lymphocyte-rich Hodgkin Lymphoma. Appl Immunohistochem Mol Morphol (in press)

39. Slack GW, Ferry JA, Hasserjian RP, Sohani AR, Longtine JA, Harris NL, Zukerberg LR (2009) Lymphocyte depleted Hodgkin lymphoma: an evaluation with immunophenotyping and genetic analysis. Leuk Lymphoma 50:937-943

40. Schraders M, van Reijmersdal SV, Kamping EJ, van Krieken $\mathrm{JH}$, van Kessel AG, Groenen PJ, Hoogerbrugge PM, Kuiper RP (2009) High-resolution genomic profiling of pediatric lymphoblastic lymphomas reveals subtle differences with pediatric acute lymphoblastic leukemias in the B-lineage. Cancer Genet Cytogenet 191:27-33
41. Schniederjan SD, Osunkoya AO (2009) Lymphoid neoplasms of the urinary tract and male genital organs: a clinicopathological study of 40 cases. Mod Pathol 22:1057-1065

42. Validire P, Capovilla M, Asselain B, Kirova Y, Goudefroye R, Plancher C, Fourquet A, Zanni M, Gaulard P, Vincent-Salomon A, Decaudin D (2009) Primary breast non-Hodgkin's lymphoma: a large single center study of initial characteristics, natural history, and prognostic factors. Am J Hematol 84:133-139

43. Mozos A, Ye H, Chuang WY, Chu JS, Huang WT, Chen HK, Hsu YH, Bacon CM, Du MQ, Campo E, Chuang SS (2009) Most primary adrenal lymphomas are diffuse large B-cell lymphomas with non-germinal center B-cell phenotype, BCL6 gene rearrangement and poor prognosis. Mod Pathol (in press)

44. Yin CC, Lin KI, Ketterling RP, Knudson RA, Medeiros LJ, Barron LL, Huh YO, Luthra R, Keating MJ, Abruzzo LV (2009) Chronic lymphocytic leukemia With $\mathrm{t}(2 ; 14)(\mathrm{p} 16 ; \mathrm{q} 32)$ involves the BCL11A and IgH genes and is associated with atypical morphologic features and unmutated $\mathrm{IgVH}$ genes. Am J Clin Pathol 131:663

45. Dong HY, Weisberger J, Liu Z, Tugulea S (2009) Immunophenotypic analysis of $\mathrm{CD} 103+\mathrm{B}$-lymphoproliferative disorders: hairy cell leukemia and its mimics. Am J Clin Pathol 131:586595

46. Robertus JL, Harms G, Blokzij1 T, Booman M, de Jong D, van Imhoff G, Rosati S, Schuuring E, Kluin P, van den Berg A (2009) Specific expression of miR-17-5p and miR-127 in testicular and central nervous system diffuse large B-cell lymphoma. Mod Pathol 22:547-555

47. Schraders M, Oeschger S, Kluin PM, Hebeda K, Schuuring E, Groenen PJ, Hansmann ML, van Krieken JH (2009) Hypermutation in mantle cell lymphoma does not indicate a clinical or biological subentity. Mod Pathol 22:416-425

48. Toracchio S, Ota H, de Jong D, Wotherspoon A, Rugge M, Graham DY, Samani A, El-Zimaity HM (2009) Translocation t $(11 ; 18)(\mathrm{q} 21 ; \mathrm{q} 21)$ in gastric B-cell lymphomas. Cancer Sci 100:881-887

49. Kanellis G, Roncador G, Arribas A, Mollejo M, Montes-Moreno S, Maestre L, Campos-Martin Y, Ríos Gonzalez JL, MartinezTorrecuadrada JL, Sanchez-Verde L, Pajares R, Cigudosa JC, Martin MC, Piris MA (2009) Identification of MNDA as a new marker for nodal marginal zone lymphoma. Leukemia (in press)

50. Leich E, Salaverria I, Bea S, Zettl A, Wright G, Moreno V, Gascoyne RD, Chan WC, Braziel RM, Rimsza LM, Weisenburger DD, Delabie J, Jaffe ES, Lister A, Fitzgibbon J, Staudt LM, Hartmann EM, Mueller-Hermelink HK, Campo E, Ott G, Rosenwald A (2009) Follicular lymphomas with and without translocation $\mathrm{t}(14 ; 18)$ differ in gene expression profiles and genetic alterations. Blood 114:826-834

51. Gu K, Fu K, Jain S, Liu Z, Iqbal J, Li M, Sanger WG, Weisenburger DD, Greiner TC, Aoun P, Dave BJ, Chan WC (2009) $\mathrm{t}(14 ; 18)$-negative follicular lymphomas are associated with a high frequency of BCL6 rearrangement at the alternative breakpoint region. Mod Pathol. [Epub ahead of print]

52. Howard MT, Dufresne S, Swerdlow SH, Cook JR (2009) Follicular lymphoma of the spleen: multiparameter analysis of 16 cases. Am J Clin Pathol 131:656-662

53. Mollejo M, Rodríguez-Pinilla MS, Montes-Moreno S, Algara P, Dogan A, Cigudosa JC, Juarez R, Flores T, Forteza J, Arribas A, Piris MA (2009) Splenic follicular lymphoma: clinicopathologic characteristics of a series of 32 cases. Am J Surg Pathol 33:730-738

54. Obermann EC, Csato M, Dirnhofer S, Tzankov A (2009) Aberrations of the MYC gene in unselected cases of diffuse large B-cell lymphoma are rare and unpredictable by morphological or immunohistochemical assessment. J Clin Pathol 62:754-756 
55. Molina-Privado I, Rodríguez-Martínez M, Rebollo P, MartínPérez D, Artiga MJ, Menárguez J, Flemington EK, Piris MA, Campanero MR (2009) E2F1 expression is deregulated and plays an oncogenic role in sporadic Burkitt's lymphoma. Cancer Res 69:4052-4058

56. Korać P, Peran I, Skrtić A, Ajduković R, Kristo DR, Dominis M (2009) FOXP1 expression in monoclonal gammopathy of undetermined significance and multiple myeloma. Pathol Int $59: 354-358$

57. Verbeek WH, von Blomberg BM, Coupe VM, Daum S, Mulder CJ, Schreurs MW, Aberrant (2009) T-lymphocytes in refractory coeliac disease are not strictly confined to a small intestinal intraepithelial localization. Cytometry B Clin Cytom (in press)

58. Cho YU, Chi HS, Park CJ, Jang S, Seo EJ, Huh J (2009) Distinct features of angioimmunoblastic T-cell lymphoma with bone marrow involvement. Am J Clin Pathol 131:640-646

59. Huang Y, Moreau A, Dupuis J, Streubel B, Petit B, Le Gouill S, Martin-Garcia N, Copie-Bergman C, Gaillard F, Qubaja M, Fabiani B, Roncador G, Haioun C, Delfau-Larue MH, Marafioti T, Chott A, Gaulard P (2009) Peripheral T-cell lymphomas with a follicular growth pattern are derived from follicular helper $\mathrm{T}$ cells (TFH) and may show overlapping features with angioimmunoblastic T-cell lymphomas. Am J Surg Pathol 33:682-690

60. Falchook GS, Vega F, Dang NH, Samaniego F, Rodriguez MA, Champlin RE, Hosing C, Verstovsek S, Pro B (2009) Hepatosplenic gamma-delta T-cell lymphoma: clinicopathological features and treatment. Ann Oncol 20:1080-1085

61. Shaw GR, Naik VS (2008) The gammadelta variant of T cell large granular lymphocyte leukemia is very similar to the common alphabeta type: report of two cases. J Hematop 1:139-143

62. Buxton D, Bacchi CE, Gualco G, Weiss LM, Zuppan CW, Rowsell EH, Huang Q, Wang J (2009) Frequent expression of CD99 in anaplastic large cell lymphoma: a clinicopathologic and immunohistochemical study of 160 cases. Am J Clin Pathol 131:574-579

63. Beltraminelli H, Leinweber B, Kerl H, Cerroni L (2009) Primary cutaneous CD4+ small-/medium-sized pleomorphic T-cell lymphoma: a cutaneous nodular proliferation of pleomorphic $\mathrm{T}$ lymphocytes of undetermined significance? A study of 136 cases. Am J Dermatopathol 31:317-322

64. Sato Y, Kojima M, Takata K, Morito T, Asaoku H, Takeuchi T, Mizobuchi K, Fujihara M, Kuraoka K, Nakai T, Ichimura K, Tanaka T, Tamura M, Nishikawa Y, Yoshino T (2009) Systemic IgG4-related lymphadenopathy: a clinical and pathologic comparison to multicentric Castleman's disease. Mod Pathol 22:589599

65. Chen D, Law ME, Theis JD, Gamez JD, Caron LB, Vrana JA, Dogan A (2009) Clinicopathologic features of CDK6 translocation-associated B-cell lymphoproliferative disorders. Am J Surg Pathol 33:720-729

66. Gibson SE, Hsi ED (2009) Epstein-Barr virus-positive B-cell lymphoma of the elderly at a United States tertiary medical center: an uncommon aggressive lymphoma with a nongerminal center B-cell phenotype. Hum Pathol 40:653-661

67. Maeshima AM, Taniguchi H, Nomoto J, Maruyama D, Kim SW, Watanabe T, Kobayashi Y, Tobinai K, Matsuno Y (2009) Secondary CD5+ diffuse large B-cell lymphoma not associated with transformation of chronic lymphocytic leukemia/small lymphocytic lymphoma (Richter syndrome). Am J Clin Pathol 131:339-346

68. Hatanaka K, Nakamura N, Kojima M, Ando K, Irie S, Bunno M, Nakamine H, Uekusa T (2009) Methotrexate-associated lymphoproliferative disorders mimicking angioimmunoblastic T-cell lymphoma. Pathol Res Pract (in press)
69. Dunleavy K, Pittaluga S, Czuczman MS, Dave SS, Wright G, Grant N, Shovlin M, Jaffe ES, Janik JE, Staudt LM, Wilson WH (2009) Differential efficacy of bortezomib plus chemotherapy within molecular subtypes of diffuse large B-cell lymphoma. Blood 113:6069-6076

70. Jiang L, Yuan CM, Hubacheck J, Janik JE, Wilson W, Morris JC, Jasper GA, Stetler-Stevenson M (2009) Variable CD52 expression in mature $\mathrm{T}$ cell and $\mathrm{NK}$ cell malignancies: implications for alemtuzumab therapy. $\mathrm{Br} \mathrm{J}$ Haematol 145:173-179

71. Troncone G, Guerriero E, Pallante P, Berlingieri MT, Ferraro A, Del Vecchio L, Gorrese M, Mariotti E, Iaccarino A, Palmieri EA, Zeppa P, Palombini L, Fusco A (2009) UbcH10 expression in human lymphomas. Histopathology 54:731-740

72. Marquard L, Poulsen CB, Gjerdrum LM, de Nully Brown P, Christensen IJ, Jensen PB, Sehested M, Johansen P, Ralfkiaer E (2009) Histone deacetylase 1, 2, 6 and acetylated histone H4 in B- and T-cell lymphomas. Histopathology 54:688-698

73. Diepstra A, van Imhoff GW, Schaapveld M, Karim-Kos H, van den Berg A, Vellenga E, Poppema S (2009) Latent Epstein-Barr virus infection of tumor cells in classical Hodgkin's lymphoma predicts adverse outcome in older adult patients. J Clin Oncol 27:3815-3821

74. Johnson NA, Leach S, Woolcock B, deLeeuw RJ, Bashashati A, Sehn LH, Connors JM, Chhanabhai M, Brooks-Wilson A, Gascoyne RD (2009) CD20 mutations involving the rituximab epitope are rare in diffuse large B-cell lymphomas and are not a significant cause of R-CHOP failure. Haematologica 94:423-427

75. Sánchez-Espiridión B, Sánchez-Aguilera A, Montalbán C, Martin C, Martinez R, González-Carrero J, Poderos C, Bellas C, Fresno MF, Morante C, Mestre MJ, Mendez M, Mazorra F, Conde E, Castaño A, Sánchez-Godoy P, Tomas JF, Morente MM, Piris MA, García JF (2009) Spanish Hodgkin's Lymphoma Study Group. A TaqMan low-density array to predict outcome in advanced Hodgkin's lymphoma using paraffinembedded samples. Clin Cancer Res 15:1367-1375

76. Canioni D, Deau-Fischer B, Taupin P, Ribrag V, Delarue R, Bosq J, Rubio MT, Roux D, Vasiliu V, Varet B, Brousse N, Hermine O (2009) Prognostic significance of new immunohistochemical markers in refractory classical Hodgkin lymphoma: a study of 59 cases. PLoS One 4:e6341

77. Bhagavathi S, Gu K, Loberiza FR, Bast M, Vose JM, Weisenburger DD (2009) Does a diffuse growth pattern predict for survival in patients with low-grade follicular lymphoma? Leuk Lymphoma 50:900-903

78. Carreras J, Lopez-Guillermo A, Roncador G, Villamor N, Colomo L, Martinez A, Hamoudi R, Howat WJ, Montserrat E, Campo E (2009) High numbers of tumor-infiltrating programmed cell death 1-positive regulatory lymphocytes are associated with improved overall survival in follicular lymphoma. J Clin Oncol 27:1470-1476

79. Koster A, Tromp HA, Raemaekers JM, Borm GF, Hebeda K, Mackenzie MA, van Krieken JH (2007) The prognostic significance of the intra-follicular tumor cell proliferative rate in follicular lymphoma. Haematologica 92:184-190

80. Koster A, van Krieken JH, Mackenzie MA, Schraders M, Borm GF, van der Laak JA, Leenders W, Hebeda K, Raemaekers JM (2005) Increased vascularization predicts favorable outcome in follicular lymphoma. Clin Cancer Res 11:154-161

81. Han SL, Wu XL, Wan L, Zeng QQ, Li JL, Liu Z (2009) FOXP1 expression predicts polymorphic histology and poor prognosis in gastric mucosa-associated lymphoid tissue lymphomas. Dig Surg 26:156-162

82. Sumida T, Kitadai Y, Hiyama T, Shinagawa K, Tanaka M, Kodama M, Masuda H, Ito M, Tanaka S, Yoshihara M, Chayama K (2009) Antibodies to Helicobacter pylori and CagA protein are 
associated with the response to antibacterial therapy in patients with $\mathrm{H}$. pylori-positive API2-MALT1-negative gastric MALT lymphoma. Cancer Sci 100:1075-1081

83. Ilić I, Mitrović Z, Aurer I, Basić-Kinda S, Radman I, Ajduković R, Labar B, Dotlić S, Nola M (2009) Lack of prognostic significance of the germinal-center phenotype in diffuse large B-cell lymphoma patients treated with CHOP-like chemotherapy with and without rituximab. Int $\mathrm{J}$ Hematol 90:74-80

84. Morito T, Fujihara M, Asaoku H, Tari A, Sato Y, Ichimura K, Tanaka T, Takata K, Tamura M, Yoshino T (2009) Serum soluble interleukin-2 receptor level and immunophenotype are prognostic factors for patients with diffuse large B-cell lymphoma. Cancer Sci 100:1255-1260

85. Johnson NA, Savage KJ, Ludkovski O, Ben-Neriah S, Woods R, Steidl C, Dyer MJ,Siebert R, Kuruvilla J, Klasa R, Connors JM, Gascoyne RD, Horsman DE (2009) Lymphomas with concurrent BCL2 and MYC translocations: the critical factors associated with survival. Blood (in press)

86. Balague O, Mozos A, Martinez D, Hernandez L, Colomo L, Mate JL, Teruya-Feldstein J, Lin O, Campo E, Lopez-Guillermo A, Martinez A (2009) Activation of the endoplasmic reticulum stress-associated transcription factor $\mathrm{x}$ box-binding protein-1 occurs in a subset of normal germinal-center B cells and in aggressive B-cell lymphomas with prognostic implications. Am J Pathol 174:2337-2346

87. Soltani-Arabshahi R, Leboeuf C, Rivet J, Pisonero H, Zhao WL, Bachelez H, Ameisen JC, Janin A (2009) Bcl-xL gene expression correlated with lower apoptotic cell numbers and shorter progression-free survival in PCFCL. J Invest Dermatol 129:1703-1709

88. Curry CV, Ewton AA, Olsen RJ, Logan BR, Preti HA, Liu YC, Perkins SL, Chang CC (2009) Prognostic impact of C-REL expression in diffuse large B-cell lymphoma. J Hematop 2:20-26

89. Kim JE, Singh RR, Cho-Vega JH, Drakos E, Davuluri Y, Khokhar FA, Fayad L, Medeiros LJ, Vega F (2009) Sonic hedgehog signaling proteins and ATP-binding cassette G2 are aberrantly expressed in diffuse large B-Cell lymphoma. Mod Pathol (in press)

90. Briones J, Moga E, Espinosa I, Vergara C, Alvarez E, Villa J, Bordes R, Delgado J, Prat J, Sierra J (2009) Bcl-10 protein highly correlates with the expression of phosphorylated p65 NF-kappaB in peripheral T-cell lymphomas and is associated with clinical outcome. Histopathology 54:478-485

91. Kim WY, Jeon YK, Kim TM, Kim JE, Kim YA, Lee SH, Kim DW, Heo DS, Kim CW (2009) Increased quantity of tumorinfiltrating FOXP3-positive regulatory $\mathrm{T}$ cells is an independent predictor for improved clinical outcome in extranodal NK/Tcelllymphoma. Ann Oncol (in press)

92. Vidulich KA, Talpur R, Bassett RL, Duvic M (2009) Overall survival in erythrodermic cutaneous T-cell lymphoma: an analysis of prognostic factors in a cohort of patients with erythrodermic cutaneous T-cell lymphoma. Int $\mathrm{J}$ Dermatol 48:243-252

93. Woo DK, Jones CR, Vanoli-Storz MN, Kohler S, Reddy S, Advani R, Hoppe RT, Kim YH (2009) Prognostic factors in primary cutaneous anaplastic large cell lymphoma:characterization of clinical subset with worse outcome. Arch Dermatol 145:667-674

94. Chandra P, Plaza JA, Zuo Z, Diwan AH, Koeppen H, Duvic M, Medeiros LJ, Prieto VG (2009) Clusterin expression correlates with stage and presence of large cells in mycosis fungoides. Am J Clin Pathol 131:511-515

95. Quereux G, Frot AS, Brocard A, Leux C, Renaut JJ, Dreno B (2009) Routine bone marrow biopsy in the initial evaluation of primary cutaneous B-cell lymphoma does not appear justified. Eur J Dermatol 19:216-220

96. Baiyee D, Warnke R, Natkunam Y (2009) Lack of utility of CD20 immunohistochemistry in staging bone marrow biopsies for diffuse large B-cell lymphoma. Appl Immunohistochem Mol Morphol 17:93-95

97. Ilgenfritz RB, Kayasut K, Le Tourneau A, Calendini OA, Ouafi L, Marzac C, Diebold J, Devez F, Ducruit V, Bouchet PE, Audouin J, Molina TJ (2009) Correlation between molecular and histopathological diagnoses of B cell lymphomas in bone marrow biopsy and aspirates. J Clin Pathol 62:357-360

98. Quijano S, López A, Manuel Sancho J, Panizo C, Debén G, Castilla C, Antonio García-Vela J, Salar A, Alonso-Vence N, González-Barca E, Peñalver FJ, Plaza-Villa J, Morado M, García-Marco J, Arias J, Briones J, Ferrer S, Capote J, Nicolás C, Orfao A (2009) Spanish Group for the Study of CNS Disease in NHL. Identification of leptomeningeal disease in aggressive B-cell non-Hodgkin's lymphoma: improved sensitivity of flow cytometry. J Clin Oncol 27:1462-1469

99. Wu JM, Georgy MF, Burroughs FH, Weir EG, Rosenthal DL, Ali SZ (2009) Lymphoma, leukemia, and pleiocytosis in cerebrospinal fluid: Is accurate cytopathologic diagnosis possible based on morphology alone? Diagn Cytopathol (in press)

100. Das DK, Francis IM, Sharma PN, Sathar SA, John B, George SS, Mallik MK, Sheikh ZA, Haji BE, Pathan SK, Madda JP, Mirza K, Ahmed MS, Junaid TA (2009) Hodgkin's lymphoma: diagnostic difficulties in fine-needle aspiration cytology. Diagn Cytopathol 37:564-573

101. Demurtas A, Accinelli G, Pacchioni D, Godio L, Novero D, Bussolati G, Palestro G, Papotti M, Stacchini A (2009) Utility of Flow Cytometry Immunophenotyping in Fine-needle Aspirate Cytologic Diagnosis of Non-Hodgkin Lymphoma: A Series of 252 Cases and Review of the Literature. Appl Immunohistochem Mol Morphol (in press)

102. Fromm JR, Thomas A, Wood BL (2009) Flow cytometry can diagnose classical Hodgkin lymphoma in lymph nodes with high sensitivity and specificity. Am J Clin Pathol 131:322-332

103. Sugita S, Takase H, Sugamoto Y, Arai A, Miura O, Mochizuki M (2009) Diagnosis of intraocular lymphoma by polymerase chain reaction analysis and cytokine profiling of the vitreous fluid. Jpn J Ophthalmol 53:209-214

104. Pantanelli SM, Li Z, Fariss R, Mahesh SP, Liu B, Nussenblatt RB (2009) Differentiation of malignant B-lymphoma cells from normal and activated T-cell populations by their intrinsic autofluorescence. Cancer Res 69:4911-4917

105. Fan HB, Zhu YF, Chen AS, Zhou MX, Yan FM, Ma XJ, Zhou H (2009) B-cell clonality in the liver of hepatitis C virus-infected patients. World J Gastroenterol 15:1636-1640

106. Hebeda KM, Van Altena MC, Rombout P, Van Krieken JH, Groenen PJ (2009) PCR clonality detection in Hodgkin lymphoma. J Hematop 2:34-41

107. Miguet L, Béchade G, Fornecker L, Zink E, Felden C, Gervais C, Herbrecht R, van Dorsselaer A, Mauvieux L, SanglierCianferani S (2009) Proteomic analysis of malignant B-cell derived microparticles reveals CD148 as a potentially useful antigenic biomarker for mantle cell lymphoma diagnosis. J Proteome Res 8:3346-3354

108. Romesser PB, Perlman DH, Faller DV, Costello CE, McComb ME, Denis GV (2009) Development of a malignancy-associated proteomic signature for diffuse large B-cell lymphoma. Am J Pathol 175:25-35

109. Jansen C, Hebeda KM, Linkels M, Grefte JM, Raemaekers JM, van Krieken JH, Groenen PJ (2008) Protein profiling of B-cell lymphomas using tissue biopsies: A potential tool for small samples in pathology. Cell Oncol 30:27-38 